\title{
Analysis of Post-90s Migrant Workers' Working and Living Status and the Willingness to Settle
}

\author{
Yuan Zhou \\ Management School, Jiangsu University, Zhenjiang, Jiangsu, China \\ Tourism Institute, Yangzhou University, Yangzhou, Jiangsu, China.
}

\begin{abstract}
Using the dynamic monitoring survey data of health workers in the floating population in 2015, the Post-90s migrant workers were identified. Based on the analysis of the working life of the city, the Binary Logistic Analysis model is used to explore the Post-90s migrant workers' willingness to settle and its influencing factors. Research shows that Post-90s migrant workers' urban settlement intention is low and the mobility is still large; the level of education, children, the number of people living together, monthly income, employment status, the nature of the unit, flow range and region which flows into will have a significant impact on Post-90s migrant workers to settle; while gender, spouse, parents and family affluence have no significant effect.
\end{abstract}

Keywords-Post-90s migrant workers; settle intention; Logistic Analysis

\section{INTRODUCTION}

The initial academic researches on Post-90s migrant workers mainly carry out in the aspects of the characteristics of the group, vocational ability and so on [1] [2], in order to discuss the various realistic problems encountered in social life. According to the National plan for 12th Five-Year, the urban settlement of rural migrant workers was regarded as an important issue to promote urbanization [3], the problem of the settlement of the migrant workers in cities and social integration has aroused great concern from the government and academia in recent years. Some scholars have investigated and discussed the urban settlement willingness of the new generation of migrant workers and its influencing factors, and achieved quite a few results [4] [5] [6]. However, the results of targeted discussions on the issue of settlement of Post-90s group are still relatively few. Considering that the current Post90s group coincides with the age of 18 to 27 years old, it is the age of identifying themselves and planning their future. Understanding the basic state of their working life in cities and whether there is a willingness to settle in cities that can effectively manage the needs of this group, and then through the correct guidance to help them to get rid of the embarrassing situation of "dual marginalization of urban and rural areas" .

\section{DATA SOURCES}

As to the definition of migrant workers, there are generally two explanations in academia today. One is the rural labor force that flow from the countryside to work and live in cities and holds rural household registration [7]. The other is the rural labor force who holds rural household registration and grows up in rural areas and did not receive higher education in continuing education experience, meanwhile the ages are between 16 and 60 and now are employed or do business in cities [8]. This paper refers to the first explanation, thus chooses item $\mathrm{F}$ of question 101, household registration was selected as "1 agriculture" among the total sample, and item L, the reason for the flow was "1 worker or doing business". At the same time, item C, the date of birth, was born on 1990 or younger, thus there remains a total of 22915 valid data, this part of the sample from the national scope corresponds with the definition of Post-90s migrant workers in this article and the needs of this study.

\section{EMPIRICAL ANALYSIS}

\section{A. Establishment and Quantification of Dependent and Independent Variables}

In this paper, the settlement willingness of Post-90s migrant workers is regarded as dependent variable, if there is a clear intention to settle, it is coded as 1 , and if there is no explicit willingness to settle, it is encoded as 0 . Because the dependent variable belongs to dichotomous variable, it is suitable to adopt probabilistic model. Therefore, in this paper, the binary Logistic regression model is used to estimate the parameters. The Logistic regression model is a common method to analyze the explained variables in classification. The basic expression is [9]:

$$
\begin{gathered}
P_{j=\mathrm{F}}\left(\alpha+\sum_{i=1}^{m} \beta_{i} x_{j i}+\mu\right)_{=1 /}\left[1+e^{-\left(\alpha+\sum_{i=1}^{m} \beta_{i} x_{j i}+\mu\right)}\right] \\
\ln \frac{P_{j}}{1-P_{j}} \alpha+\sum_{i=1}^{m} \beta_{i} x_{j i}
\end{gathered}
$$

Among them, $\mathrm{P}$ indicates the probability of willingness to settle (willing to settle, not willing to settle) of Post-90s migrant workers, expresses the ith influencing factor, expresses the regression coefficient of the ith,$\alpha$ expresses intercept term and $\mu$ expresses error term.

The selection of independent variables according to the above working and living situation and the influencing factors of settlement willingness of Post-90s migrant workers, from the individual characteristics, family situation, social and 
economic status and the characteristics of the flow these four dimensions(see Table I. There is a brief explanation of variables as follows. In personal characteristics, select the "first marriage" and "remarriage" in the questionnaire encoding for the spouse, choose "not married", "divorce" and "widowed" encoding for no spouse in the local family. The number of local residents received according to the questionnaire item 101 "please talk about you, your spouse and children and other members of the family living in the family". The information of with the companion of parents or children was coded according to whether "5 parents/parents-in-law" or "3 children" were checked in the questionnaire item 101 "relationship with the interviewees". Since most of the Post-90s migrant workers were living alone, household income and expenditure is difficult to accurately measure the degree of family affluence, so this article chooses Engel coefficient to measure the degree of wealth. According to the questionnaire item 103, "in the past year, how much is your family average monthly food expenditure in the local area?" and item 105 "how much is the average monthly total expenditure of your family in the past year?", calculated the Engel coefficient of the family. And according to the United Nations criteria, divided them into poverty $(>60 \%)$, dress warmly and eat one's fill $(50 \%-60 \%)$, well-off $(40 \%-50 \%)$ and prosperous $(40 \%)$. The monthly income in the social and economic status is based on the monthly income data of the Post-90s migrant workers, and it is converted into multiple categories of income. Gender, education level, employment status, and the nature of the company, the flow range and inflow region and other corresponding variables are directly coded according to the corresponding items in the questionnaire.

\section{B. Results and Analysis}

The For the Logistic regression model, the applicability of Nagelkerke R square or -2Loglike hood value is poor, so the Hosmer-Lemeshow test is chosen as the index of goodness of fit of equation. Through Hosmer-Lemeshow test, it is found that both chi-square value and Sig value have passed the test, which shows that the Logistic model has a good degree of fitting, and has statistical sense. The following is a detailed analysis of the affecting factors of the Post-90s migrant workers' willingness to settle down (see Table I).

TABLE I. THE RESULTS OF LOGISTIC REGRESSION ANALYSIS OF INFLUENCING FACTORS OF POST-90S MIGRANT WORKERS' WILLINGNESS TO SETTLE

\begin{tabular}{|c|c|c|c|c|}
\hline \multirow{2}{*}{ variables } & \multicolumn{3}{|c|}{ Settlement willing } & \multirow[b]{2}{*}{$\operatorname{Exp}(\mathrm{B})$} \\
\hline & B & SE & Sig & \\
\hline \multicolumn{5}{|l|}{ gender (female=Reference group) } \\
\hline male & -.039 & 0.30 & 0.193 & 0.962 \\
\hline \multicolumn{5}{|l|}{ Marital status (unmarried=Reference group ) } \\
\hline married & -.058 & 0.050 & 0.246 & 0.944 \\
\hline $\begin{array}{c}\text { Educational level (Junior secondary school and } \\
\text { below=Reference group) }\end{array}$ & & & 0.000 & \\
\hline High school and technical secondary school & $0.212 * * *$ & 0.032 & 0.000 & 1.236 \\
\hline junior college education & $0.648 * * *$ & 0.050 & 0.000 & 1.912 \\
\hline Undergraduate and above & $0.717 * * *$ & 0.090 & 0.000 & 2.048 \\
\hline Family affluence（Poor=Reference group） & & & 0.941 & \\
\hline Dress warmly and eat one's fill & 0.009 & 0.043 & 0.833 & 1.009 \\
\hline Well-off & 0.000 & 0.046 & 0.994 & 1.000 \\
\hline Prosperous & 0.021 & 0.039 & 0.593 & 1.021 \\
\hline $\begin{array}{l}\text { the number of local resident ( } 1 \text { person } \\
=\text { Reference group) }\end{array}$ & & & 0.000 & \\
\hline 2-4 persons & $0.661 * * *$ & 0.041 & 0.000 & 1.937 \\
\hline More than 5 persons & $0.968 * * *$ & 0.083 & 0.000 & 2.633 \\
\hline \multicolumn{5}{|l|}{$\begin{array}{l}\text { With children (With no company=Reference } \\
\text { group) }\end{array}$} \\
\hline With children & $0.551 * * *$ & 0.050 & 0.000 & 1.735 \\
\hline $\begin{array}{c}\text { With parents } \begin{array}{c}\text { (With no company=Reference } \\
\text { group ) }\end{array} \\
\end{array}$ & & & & \\
\hline With parents & -0.055 & 0.038 & 0.144 & 0.946 \\
\hline
\end{tabular}




\begin{tabular}{|c|c|c|c|c|}
\hline \multicolumn{5}{|c|}{ Cont. to TABLE I } \\
\hline $\begin{array}{c}\text { Employment status (employee= Reference } \\
\text { group ) }\end{array}$ & & & 0.000 & \\
\hline employer & $0.445 * * *$ & 0.78 & 0.000 & 1.560 \\
\hline Self-employed workers & $0.225 * * *$ & 0.43 & 0.000 & 1.253 \\
\hline $\begin{array}{c}\text { Nature of companies ( State-owned and collective } \\
\text { companies=Reference group) }\end{array}$ & & & 0.000 & \\
\hline Individual and private businesses & $-0.176^{* * *}$ & 0.048 & 0.000 & 0.838 \\
\hline Foreign-funded enterprise & $-0.221 * *$ & 0.069 & 0.001 & 0.802 \\
\hline Private organizations and institutions & $0.430 * * *$ & 0.116 & 0.000 & 1.538 \\
\hline other & $-0.331 * * *$ & 0.073 & 0.000 & 0.718 \\
\hline $\begin{array}{c}\text { income (Less than } 3000 \text { yuan=Reference } \\
\text { group })\end{array}$ & & & 0.000 & \\
\hline $3000-5000$ yuan & $0.200 * * *$ & 0.033 & 0.000 & 1.221 \\
\hline More than 5000 yuan & $0.438 * * *$ & 0.057 & 0.000 & 1.549 \\
\hline $\begin{array}{l}\text { Flow range(cross-provincial mobility }=\text { Reference } \\
\text { group })\end{array}$ & & & 0.000 & \\
\hline Cross city within the province & $0.188 * * *$ & 0.036 & 0.000 & 1.207 \\
\hline Cross county within the city & $0.389 * * *$ & 0.043 & 0.000 & 1.475 \\
\hline $\begin{array}{c}\text { Inflow region }\left(\begin{array}{c}\text { Eastern region }=\text { Reference } \\
\text { group })\end{array}\right.\end{array}$ & & & 0.000 & \\
\hline Western region & 0.042 & 0.045 & 0.354 & 1.043 \\
\hline Middle part & $0.154 * * *$ & 0.037 & 0.000 & 1.166 \\
\hline Northeast region & $0.627 * * *$ & 0.072 & 0.000 & 1.871 \\
\hline \multicolumn{5}{|l|}{ Hosmer-Lemeshow test } \\
\hline Chi-square & & 8.467 & & \\
\hline $\begin{array}{r}\text { Df } \\
\text { Sig. }\end{array}$ & & $\begin{array}{c}8 \\
0.389\end{array}$ & & \\
\hline
\end{tabular}

\section{1) INDIVIDUAL CHARACTERISTICS FACTORS}

The regression results of the model showed that the regression coefficients of gender and spouse could not pass the test at the significance level of 0.05 . The results showed that the influence of gender and spouse on Post-90s migrant workers' willingness to settle was not obvious. However, the regression coefficient of education level passed the test at the significant level of 0.001 , showing that the education level has a significant influence on the Post-90s migrant workers' willingness to settle down, and shows that the higher the educational level, the stronger the influence on the settlement willingness. The likelihood of settlement willingness of Post$90 \mathrm{~s}$ migrant workers with high school and technical secondary school qualifications is $23.6 \%$ higher than those with junior secondary school and below, while the probability of the Post-90s migrant workers with undergraduate and above is as high as $100 \%$. It indicates that the education of migrant workers determines their living ability and development space in the city, and education can effectively promote the Post-90s migrant workers to settle in cities.

\section{2) FAMILY SITUATION FACTORS}

The regression coefficient of family affluence and parental concomitant condition could not pass the test at the significant level of 0.05 , which showed that the family affluence and the parental concomitant condition had no significant influence on the Post-90s migrant workers' willingness to settle down. However, the regression coefficient of children's concomitant situation passed the test, which indicated that the children's living and education situation were considered in the urban settlement decision of the Post-90s migrant workers. At the same time, the regression coefficient of the number of local residents also passed the hypothesis test. The possibility of settlement of the Post-90s migrant workers living with 2 to 4 persons was nearly twice as high as that of the Post-90s migrant workers living alone, that of the Post-90s migrant workers living with more than five people is 1.6 times higher than the new generation of migrant workers living alone, and the effect was significant.

\section{3) SOCIAL AND ECONOMIC STATUS FACTORS}

Although the results of the model show that the degree of family affluence has no significant influence on the Post-90s migrant workers' willingness to settle, the monthly income, which can largely determine the personal wealth, has a significant impact on the Post-90s migrant workers' willingness to settle down. The willingness of Post-90s migrant workers with monthly income of more than 5,000 yuan to settle down is 0.5 times higher than that of Post-90s migrant workers below 3,000 yuan, indicating that the personal income target is a major driving force and guarantee for Post-90s migrant workers to settle in cities. 
In terms of occupation, compared with state-owned and collective companies, the settlement willingness of Post-90s migrant workers who work in private, foreign and other enterprises are lower than those of state-owned and collective enterprises. However, the Post-90s migrant workers who work in private organizations and institutions are $53.8 \%$ more likely to settle down than state-owned and collective enterprises. This shows that such more stable jobs in institutions play a significant role in promoting the settlement of Post-90s migrant workers. Similarly, employment status also has a significant impact on Post-90s migrant workers' willingness to settle down. Employers and self-employed workers are more willing to settle, and their willingness to settle is $25 \%$ higher than that of employees. Therefore, it indicates that the economic base is a key factor for migrant workers to settle in cities.

\section{4) FLOW DISTRIBUTION FACTORS}

The range of mobility has a significant effect on the willingness to settle. Compared with Post-90s migrant workers who flow outside the province, the Post-90s migrant workers who flow in the city have higher possibility of the willingness to settle, which increased by about $47.5 \%$. However, the influence of the inflow area on the settlement willingness of Post-90s migrant workers is more complicated. The Post-90s migrant workers in the northeast region have the strongest intention to settle, and the possibility of settlement of Post-90s migrant workers in the northeast region is $87.1 \%$ higher than that in the east. However, the western region has no significant impact on the settlement of Post-90s migrant workers. This shows that, for Post-90s migrant workers, when considering the region of settlement, the west is no different from the east. It is due to the rapid economic development of the western region in recent years, living standards have improved significantly, and have a strong attraction to the Post-90s migrant workers. At the same time, the high living cost in the eastern region also makes a considerable number of post-90s migrant workers prohibitive.

\section{CONCLUSIONS}

From the above analysis, the following basic conclusions are obtained:

(1) The urban settlement willingness of the Post-90s migrant workers is low, and the mobility is still very high. The factors that have significant influence on the Post-90s migrant workers' settlement willingness are: education level, the number of people living together, monthly income, the nature of companies, employment status, flow range, inflow region, while gender, spouse, family affluence and with the companion of parents have no significant effect.

(2) Social integration is the key to enhance the willingness of Post-90s migrant workers to settle. According to the study of this paper, compared with cross-provincial mobility, Post-90s migrant workers whose flow is interprovincial, inter-city are more willing to settle. At the same time, the number of people living together also has a significant impact on the promotion of the willingness of Post-90s migrant workers to settle.

\section{REFERENCES}

[1] Wang X. Z. 2013. "On the Essential Characteristics of Peasant Workers Born in the 1990s--A Case Study of the Pearl River Delta," Journal of Guangxi University for Nationalities (Philosophy and Social Science Edition), 1: 128-133,(In Chinese )

[2] Liu F. T. 2012. "Discussion on the cultivation of the Vocational ability of the Post-90s migrant workers," Social Scientist, 8: 105108.(In Chinese )

[3] Wang Y. J.2013. "Settlement Intention of Rural Migrants in Chinese Cities: Findings from a Twelve-city Migrant Survey," Population Research, 37(4):19-32.(In Chinese )

[4] Yao Z.F. and Xue J. H. 2014. "Study on Capital, Cognitive Influence of the New-age Peasant Workers," Population Journal, 36(3):107112.(In Chinese )

[5] Xia X. L., Yao Z. F., Li Y. and He Q. 2012. "Study on the Factors of the New Generation Peasant Workers Settled in the City," Population Journal, 4:73-80.(In Chinese )

[6] Luo X. F. and Duan C. R. 2013. "Would the New Generation of migrant workers be willing to stay in the working City? -The role of Family, Household Registration and Human Capital, "Issues in Agricultural Economy, 9:65-71.(In Chinese )

[7] Lu H. Y., Liang H. B., and Qian W. R. 2015. "Urban Integration of migrant workers: current situation and Policy Enlightenment," Issues in Agricultural Economy, 7:26-36.(In Chinese )

[8] Yang X. L., Jing Z .F. and Wang Q. B. 2014. "A study on the influence of neighbor type on Peasant Workers' settlement Choice in County-towns: based on the sampling investigation of Peasant Workers in five Counties of Liaoning Province," Journal of Agrotechnical Economics, 12: 84-94.(In Chinese )

[9] Tian X. G., Chen M. H. and Cui J.X.,2012, "Survey on farmers' willingness for training on modern distance education based on the binary logistic regression model—-Taking countrysides of Pearl River Delta as an example," Journal of Southern Agriculture,43(6):886-890.(In Chinese ) 